\title{
AgOTf-catalyzed one-pot reactions of 2-alkynylbenzaldoximes with $\alpha, \beta$-unsaturated carbonyl compounds
}

\author{
Qiuping Ding ${ }^{1}$, Dan Wang ${ }^{1}$, Puying Luo*2, Meiling Liu ${ }^{1}$, Shouzhi Pu*3 \\ and Liyun Zhou ${ }^{1}$
}

\section{Full Research Paper}

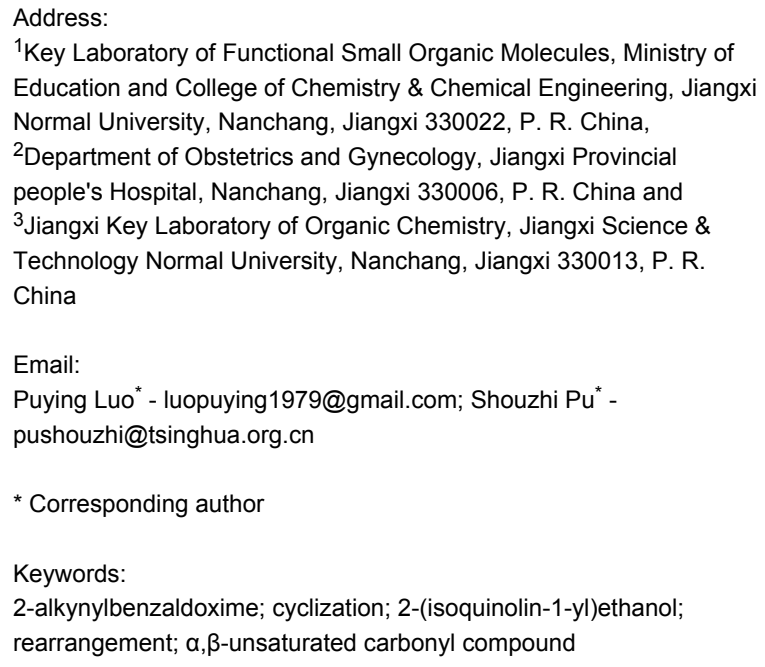

${ }^{1}$ Key Laboratory of Functional Small Organic Molecules, Ministry of Education and College of Chemistry \& Chemical Engineering, Jiangxi Normal University, Nanchang, Jiangxi 330022, P. R. China, ${ }^{2}$ Department of Obstetrics and Gynecology, Jiangxi Provincial people's Hospital, Nanchang, Jiangxi 330006, P. R. China and ${ }^{3}$ Jiangxi Key Laboratory of Organic Chemistry, Jiangxi Science \& Technology Normal University, Nanchang, Jiangxi 330013, P. R. China

Email:

Puying Luo* - luopuying1979@gmail.com; Shouzhi Pu* pushouzhi@tsinghua.org.cn

* Corresponding author

Keywords:

2-alkynylbenzaldoxime; cyclization; 2-(isoquinolin-1-yl)ethanol;

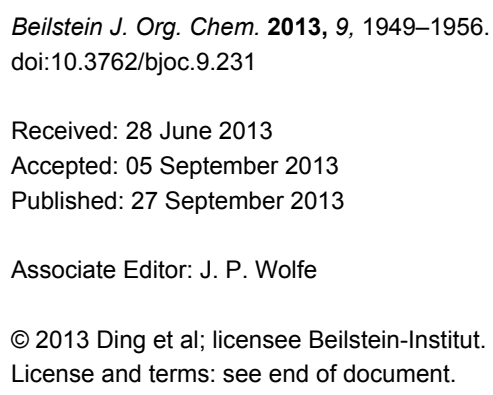

\begin{abstract}
AgOTf-catalyzed one-pot reactions of 2-alkynylbenzaldoximes with various $\alpha, \beta$-unsaturated carbonyl compounds under mild conditions are described, which provides a facile and efficient pathway for the synthesis of 1-alkylated isoquinoline derivatives. The method tolerates a wide range of substrates and allows for the preparation of the products of interest in moderate to excellent yields.
\end{abstract}

\section{Introduction}

One-pot combinations of multi-catalysis and multi-component cascade reactions [1-6], in which several bond-forming steps take place in a single operation, play an important role in atomeconomical organic chemistry. A cascade reaction is the most efficient way for targeting fine chemicals, agrochemicals, pharmaceutical drugs, drug intermediates and ingredients by a onepot reaction in environmentally and economically friendly syn- thetic processes. Isoquinoline derivatives, an important class of nitrogen-containing polycyclic heteroarenes, have attracted considerable attention because of their pharmacological activities, including antitumor, antifungal, antimalarial, antihypertensive and antihistaminic activity, and their photo- and electrochemical properties [7-15]. Over the past decade, there has been growing interest in the development of new methods for the 
construction of isoquinoline. For instance, Yamamoto [16-19], Larock [20-27], and $\mathrm{Wu}$ [28-35] have reported mild and efficient methodologies to synthesize substituted isoquinolines.

Despite the aforementioned versatile and efficient methods for the direct construction of isoquinolines, the selective functionalization of isoquinoline species is still a challenging task. Recently, there has been some progress in this aspect. $\mathrm{Wu}$ and co-workers described an efficient three-component reaction of a 2 -alkynylbenzaldoxime and an $\alpha, \beta$-unsaturated carbonyl compound with bromine or iodine monochloride under mild conditions, which generates the 1-alkylated isoquinolines in good to excellent yields [36]. Wu and co-workers also reported many other highly functionalized isoquinoline derivatives by cascade reactions in good yields under mild conditions, such as 1 -aminoisoquinolines [37] and 1-(isoquinolin-1-yl)ureas $[38,39]$. Recently, Deng and co-workers also described a new $\mathrm{Pd}$-catalyzed $\mathrm{C}-\mathrm{H}$ oxidation system for the regioselective alkylation of isoquinoline $\mathrm{N}$-oxide and its derivatives with sulfoxides for the synthesis of 1-alkylated isoquinolines [40].

We also reported the synthesis of 1-arylated 1,3-disubstituted isoquinoline $N$-oxides in a one-pot reaction characterized by a Ag-catalyzed intramolecular addition cyclization/Pd-catalyzed direct arylation of 2-alkynylbenzaldoximes [41]. Inspired by the key contributions from the groups of $\mathrm{Wu}$ [36-39] and Deng [40], we envisioned that 1-alkylated isoquinolines could be generated in a one-pot AgOTf-catalyzed cyclization/1,3-dipolar cycloaddition/rearrangement or fragmentation from 2-alkynylbenzaldoximes and $\alpha, \beta$-unsaturated carbonyl compounds.

Based on previous results [36-39,41-43], we expect 2-alkynylbenzaldoxime 1 to easily convert at room temperature to isoquinoline $\mathrm{N}$-oxide A by a AgOTf-catalyzed cyclization. Compound A produced in situ might undergo a 1,3-dipolar cycloaddition with $\alpha, \beta$-unsaturated carbonyl compound 2 leading to $2,10 \mathrm{~b}$-dihydro- $1 H$-isoxazolo[3,2- $a$ ] isoquinoline intermediate $\mathbf{B}[44,45]$, which may then suffer a rearrangement or fragmentation resulting in compound $\mathbf{3}$ (Scheme 1) $[35,36,38,42]$. To demonstrate the feasibility of this assumed route, we started to investigate the possibility of this one-pot process.

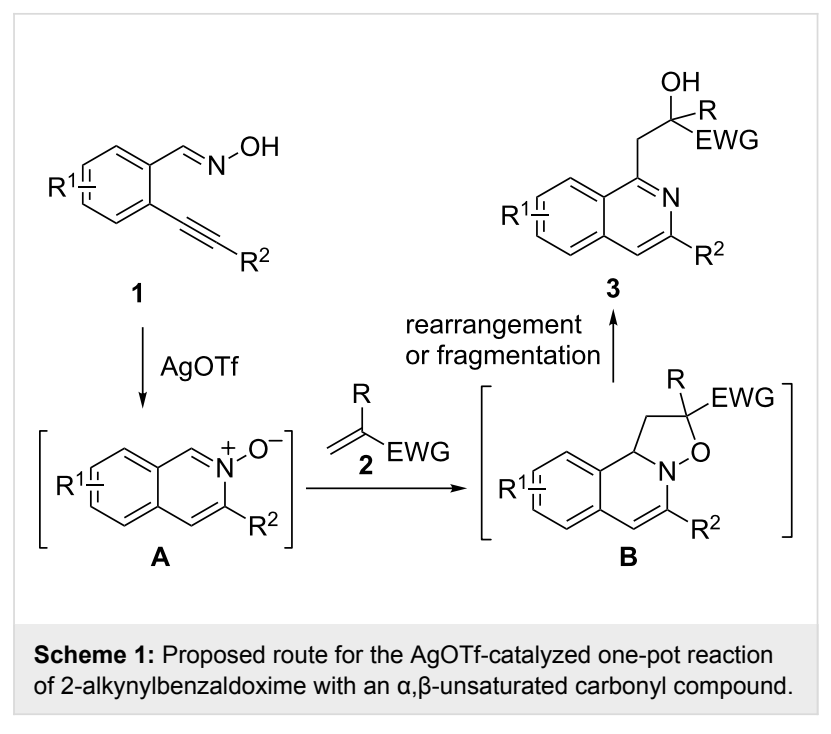

\section{Results and Discussion}

Initially, a set of experiments was carried out with 2-alkynylbenzaldoxime 1a and methyl methacrylate (2a) as model substrates in the presence of $\operatorname{AgOTf}(5 \mathrm{~mol} \%$ ). As expected, the reaction proceeded smoothly in $\mathrm{CH}_{2} \mathrm{Cl}_{2}$ at room temperature to afford the desired product $3 \mathrm{a}$ in $55 \%$ yield. We also tested other solvents, such as 1,4-dioxane, NMP, DMSO, DMA, toluene and DMF (Scheme 2). The solvent screening demonstrated that DMF was the best choice for the reaction at $60{ }^{\circ} \mathrm{C}$. From these results, it was found that this one-pot process was highly efficient to construct 1-alkylated isoquinolines under very mild conditions.

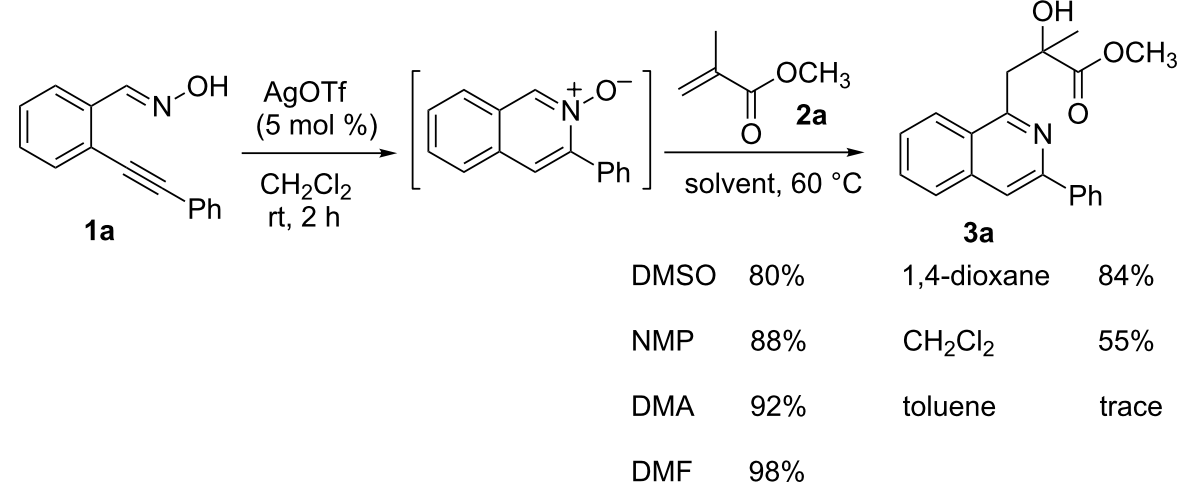


With the optimized conditions in hand, the scope of the unsaturated carbonyl compounds $\mathbf{2 a - g}$ (Table 1). In most cases, procedure was investigated for the reaction of $2-(p-$ substrate $\mathbf{1 b}$ reacted with $\alpha, \beta$-unsaturated carbonyl compounds tolylethynyl)benzaldehyde oxime (1b) with a series of $\alpha, \beta-2$ leading to the corresponding 1-alkylated isoquinolines in

Table 1: AgOTf-catalyzed one-pot reactions of 2-( $p$-tolylethynyl)benzaldehyde oxime (1b) with $\alpha, \beta$-unsaturated carbonyl compounds 2.<smiles>O/N=C/c1ccccc1C#COO</smiles><smiles>[O-][n+]1cc2ccccc2cc1O[Ga]</smiles>

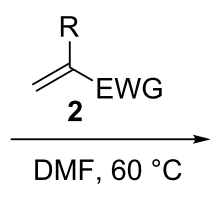

Product 3<smiles>[R]C(O)(C#[W])Cc1nc(O[Ga])cc2ccccc12</smiles>

3

\section{Entry}

2<smiles>C=C(C)C(=O)OC</smiles>

2a

2<smiles>C=C(C)C(=O)OCBr</smiles>

2b

3<smiles>C=CC(=O)OC</smiles>

2c

4<smiles>C=COC(=O)OCC</smiles>

2d

5<smiles>C=COC(=O)OCCC</smiles>

$2 e$<smiles>COC(=O)C(C)(O)Cc1nc(O[Ga])cc2ccccc12</smiles>

3b<smiles>CCCOC(=O)C(C)(O)Cc1nc(OCl)cc2ccccc12</smiles>

3c<smiles>COC(=O)C(O)Cc1nc(O[Ga])cc2ccccc12</smiles>

3d<smiles>CCO[Ge]c1cc2ccccc2c(CC(O)C(=O)OCC)n1</smiles>

3 e<smiles>CCCOC(=O)C(O)Cc1nc(O[Ga])cc2ccccc12</smiles>

$3 f$<smiles>CCC(C)OC(=O)C(O)Cc1nc(OCc2ccccc2)cc2ccccc12</smiles>

$3 \mathrm{~g}$
70 
Table 1: AgOTf-catalyzed one-pot reactions of 2-( $p$-tolylethynyl)benzaldehyde oxime (1b) with $\alpha, \beta$-unsaturated carbonyl compounds 2. (continued)

7

8

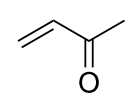

$2 \mathrm{~g}$

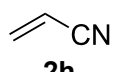<smiles>CC(=O)C(O)Cc1nc(OCc2ccccc2)cc2ccccc12</smiles>

3h<smiles>COc1cc2ccccc2c(CC(O)C#N)n1</smiles>

$3 \mathbf{i}$

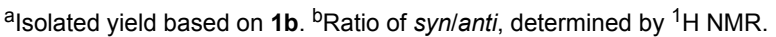

moderate to excellent yields. For instance, the reaction with $\mathbf{2 b}$ under standard conditions gave rise to the desired product $\mathbf{3 c}$ in $81 \%$ yield (Table 1 , entry 2 ). An excellent yield was observed when butyl acrylate (2e) was utilized in the reaction ( $98 \%$ yield, Table 1, entry 5). When tert-butyl acrylate (2f) was employed, the reaction led to the formation of the desired 1-alkylated product $3 \mathrm{~g}$ ( $80 \%$ yield, Table 1 , entry 6$)$ with a molar ratio of $s y n$ - and anti-isomers of $\sim 1 / 6$. It is noteworthy, that in other cases only a single product was observed. But-3-en-2one (2g) was less reactive than the investigated acrylic acid esters and delivered the desired product only in moderate yield (40\%, Table 1, entry 7$)$. On the other hand, when substrate $\mathbf{1 b}$ was treated with acrylonitrile $\mathbf{2 h}$ under such conditions, the starting materials were recovered almost completely (Table 1 , entry 8).

Next, we examined the effect of substituents at the 2-alkynylbenzaldoxime 1. In most cases, 2-alkynylbenzaldoxime $\mathbf{1}$ reacted with acrylates $\mathbf{2}$ leading to the desired products $\mathbf{3}$ in moderate to good yields. For instance, reaction of 2-((4methoxyphenyl)ethynyl)benzaldehyde oxime (1c) with methyl methacrylate (2a) under the conditions described above gave the desired product $\mathbf{3 j}$ in $75 \%$ yield (Table 2 , entry 1 ). A better yield was obtained when substrate 1e was employed in the reac- tion $(83 \%$ yield, Table 2 , entry 3 ). The usage of 2-(cyclopropylethynyl)benzaldehyde oxime (1f) in the reaction led to a similar yield ( $80 \%$ yield, Table 2 , entry 5 ). However, low yields were obtained when 2-(hex-1-yn-1-yl)benzaldehyde oxime (1g) reacted with methyl methacrylate (2a). In the case of substrate $\mathbf{1 h}\left(\mathrm{R}^{2}=\mathrm{SiMe}_{3}\right)$ only desilyl product $\mathbf{3 p}$ was observed in poor yield due to the instability of the product. When $\mathrm{R}^{2}$ was changed to $\mathrm{H}$ (2-ethynylbenzaldehyde oxime (1i), Table 2, entry $8)$, there was no reaction at all. Good yields were obtained when 2-alkynylbenzaldoximes substituted with other electron-withdrawing groups (such as $\mathbf{1 j}$ and $\mathbf{1 k}$ ) reacted with acrylate $\mathbf{2 a}$ (Table 2, entries 9-12). However, substrates with electrondonating groups attached on the aromatic ring of 2-alkynylbenzaldoxime (such as substrate 11, Table 2, entry 13) did not afford a desired product.

Recently, 1-alkenylated isoquinoline 4 was synthesized via a $\mathrm{Pd}-$ mediated $\mathrm{C}-\mathrm{H}$ bond activation approach in a one-pot reaction. The intermediate isoquinoline $N$-oxide $\mathbf{A}$ was produced in situ from 2-alkynylbenzaldoximes and reacted with the $\alpha, \beta$ unsaturated carbonyl compound 2e to yield 1-alkenylated isoquinoline 4 (Scheme 3). This observation indicated that the Palladium-catalyzed alkenylation reaction mechanism might be similar to that described by $\mathrm{Cui}$ and $\mathrm{Wu}[46]$.

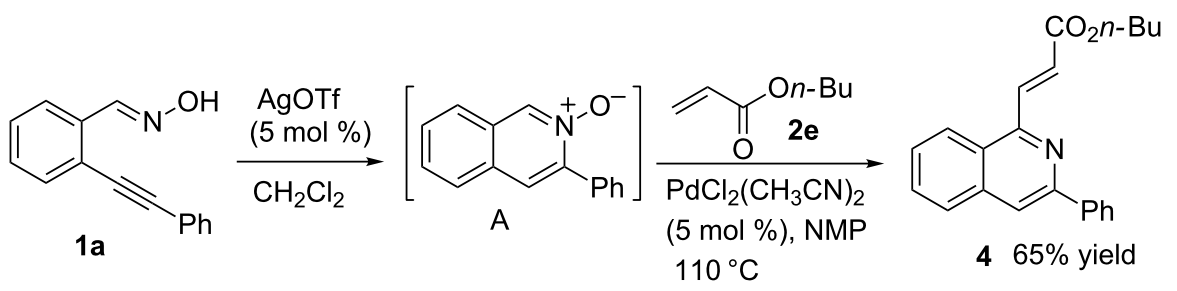


Table 2: One-pot reactions of 2-alkynylbenzaldoximes 1 with acrylates 2.

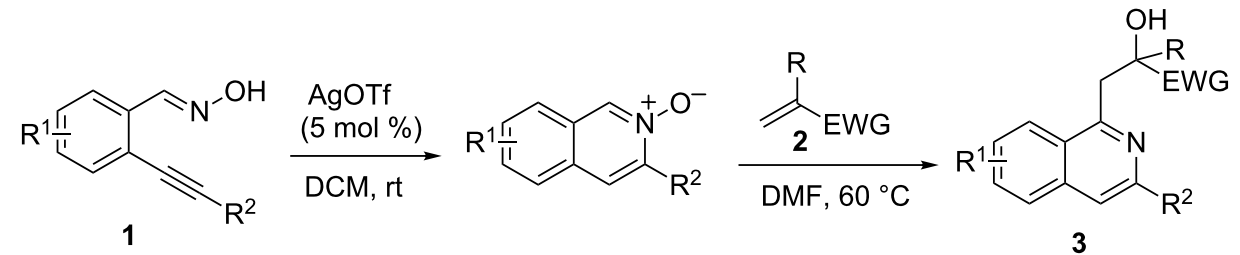

Entry 2-Alkynylbenzaldoxime 1

1c<smiles>O/N=C/c1ccccc1C#Cc1ccc(F)cc1</smiles>

1d

3<smiles>O/N=C/c1ccccc1C#Cc1cccc(F)c1</smiles>

$1 e$<smiles>O/N=C/c1ccccc1C#Cc1cccc(F)c1</smiles>

$1 e$<smiles>O/N=C/c1ccccc1C#CC1CC1</smiles>

$1 f$<smiles>CCCCOC#Cc1ccccc1/C=N/O</smiles>

$1 \mathrm{~g}$
2

Product 3

Yield $^{\mathrm{a}}(\%)$

$2 a$<smiles>COC(=O)C(C)(O)Cc1nc(N)cc2ccccc12</smiles>

3j<smiles>COC(=O)C(C)(O)Cc1nc(-c2ccc(F)cc2)cc2ccccc12</smiles>

3k<smiles>COC(=O)C(C)(O)Cc1nc(-c2cccc(F)c2)cc2ccccc12</smiles>

31<smiles>CCCOC(=O)C(O)Cc1nc(-c2cccc([SnH3])c2)cc2ccccc12</smiles><smiles>COC(=O)C(O)(Cc1nc(C2CC2)cc2ccccc12)C(=O)OC</smiles>

3n<smiles>CCCCOc1cc2ccccc2c(CC(O)(C(=O)OC)C(=O)OC)n1</smiles>

48

83

70

$(1 / 4)^{\mathrm{b}}$

80

35 
Table 2: One-pot reactions of 2-alkynylbenzaldoximes 1 with acrylates 2. (continued)

7<smiles>CC(C)(C)C#Cc1ccccc1/C=N/O</smiles>

1h<smiles>C#Cc1ccccc1/C=N/O</smiles>

$1 \mathbf{i}$<smiles>O/N=C/c1ccc(F)cc1C#Cc1ccccc1</smiles>

1j<smiles>O/N=C/c1ccc(F)cc1C#Cc1ccccc1</smiles>

1j<smiles>O/N=C/c1ccc(F)cc1C#Cc1ccccc1</smiles>

1j

12<smiles>O/N=C/c1cc(F)ccc1C#Cc1ccccc1</smiles>

1k<smiles>O/N=C/c1cc2c(cc1C#Cc1ccccc1)OCO2</smiles>

11
$2 a$<smiles>COC(=O)C(O)Cc1nccc2ccccc12</smiles>

$\mathrm{OH}$

$2 a$<smiles>COC(=O)C(O)Cc1nccc2ccccc12</smiles>

$3 p$<smiles>COC(=O)C(O)(Cc1nc(-c2ccccc2)cc2cc(F)ccc12)C(=O)O</smiles>

$3 q$<smiles>CCCOC(=O)C(O)Cc1nc(-c2ccccc2)cc2cc(F)ccc12</smiles>

$3 r$

$2 f$<smiles>CCCOC(=O)C(O)Cc1nc(-c2ccccc2)cc2cc(F)ccc12</smiles>

$3 s$<smiles>COCC(O)(Cc1nc(-c2ccccc2)cc2ccc(F)cc12)C(=O)OC</smiles>

$3 t$<smiles>COCC(O)(Cc1nc(-c2ccccc2)cc2cc3c(cc12)OCO3)C(=O)OC</smiles>

3u

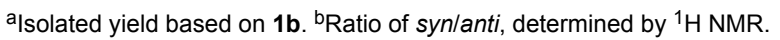

\section{Conclusion}

In summary, we have demonstrated that one-pot reactions of 2 -alkynylbenzaldoximes with $\alpha, \beta$-unsaturated carbonyl compounds catalyzed by AgOTf occur smoothly under mild conditions. The present method provides a facile and efficient pathway for the synthesis of 1-alkylated isoquinoline derivatives in moderate to excellent yields with a wide range of substrates. The present one-pot catalyst system was also found to be applicable to the synthesis of 1-alkenylated isoquinoline derivatives. 


\section{Experimental General}

All reactions were performed in test tubes under a nitrogen atmosphere. Flash column chromatography was performed with silica gel (200-300 mesh). Analytical thin-layer chromatography was performed on glass plates pre-coated with $0.25 \mathrm{~mm}$ 230-400 mesh silica gel and impregnated with a fluorescent indicator $(254 \mathrm{~nm})$. Spots on thin-layer chromatography plates were visualized by exposure to ultraviolet light. Organic solutions were concentrated on rotary evaporators at $25-35{ }^{\circ} \mathrm{C}$. Commercial reagents and solvents were used as received. ${ }^{1} \mathrm{H}$ and ${ }^{13} \mathrm{C}$ NMR spectra were recorded on a Bruker AV 400 spectrometer at $400 \mathrm{MHz}\left({ }^{1} \mathrm{H}\right)$ and $100 \mathrm{MHz}\left({ }^{13} \mathrm{C}\right)$ at ambient temperature. Chemical shifts are reported in parts per million (ppm) on the delta scale $(\delta)$ and referenced to tetramethylsilane (0 ppm). HRMS analyses were performed in ESI mode on a Bruker mass spectrometer.

General procedure for the AgOTf-catalyzed one-pot reactions of 2-alkynylbenzaldoximes 1 with $\alpha, \beta$-unsaturated carbonyl compounds 2: A mixture of 2-alkynylbenzaldoximes $\mathbf{1}$ $(0.3 \mathrm{mmol})$ and $\operatorname{AgOTf}(0.015 \mathrm{mmol}, 5 \mathrm{~mol} \%)$ in $\mathrm{CH}_{2} \mathrm{Cl}_{2}$ $(2 \mathrm{~mL})$ was stirred at room temperature for $2 \mathrm{~h}$, until 2-alkynylbenzaldoxime 1 was completely consumed. The solvent was removed under reduced pressure. Then, $\alpha, \beta$-unsaturated carbonyl compound 2 ( $1.5 \mathrm{mmol}, 5.0$ equiv) in DMF ( $1 \mathrm{~mL})$ was added to the residue, and allowed to stir at $60{ }^{\circ} \mathrm{C}$ overnight under a nitrogen atmosphere. After completion of the reaction as indicated by TLC, the reaction was quenched by water and extracted with ethyl acetate. The organic layers were dried with anhydrous $\mathrm{MgSO}_{4}$, the solvent was evaporated under reduced pressure, and the residue was purified by column chromatography with EtOAc/petroleum ether $(1: 5, \mathrm{v} / \mathrm{v})$ as an eluent to yield the desired products 3 .

Procedure for the synthesis of 1-alkenylated isoquinoline 4 by a Pd-mediated $\mathrm{C}-\mathrm{H}$ bond activation approach: A solution of 2-alkynylbenzaldoxime $\mathbf{1 a}(0.3 \mathrm{mmol})$ and AgOTf $(0.015 \mathrm{mmol}, 5 \mathrm{~mol} \%)$ in $\mathrm{CH}_{2} \mathrm{Cl}_{2}(2 \mathrm{~mL})$ was stirred at $\mathrm{rt}$ for $2 \mathrm{~h}$. Then, the solvent was removed under reduced pressure. Subsequently, a solution of $\alpha, \beta$-unsaturated carbonyl compound $2 \mathrm{e}$ (1.5 mmol, 5.0 equiv) and $\mathrm{PdCl}_{2}(\mathrm{PhCN})_{2}(5 \mathrm{~mol} \%)$ in NMP $(1 \mathrm{~mL})$ was added to the residue, and allowed to stir overnight at $110^{\circ} \mathrm{C}$ under a nitrogen atmosphere. After completion of the reaction as indicated by TLC, the reaction was quenched by water and extracted with ethyl acetate. The organic layers were dried with anhydrous $\mathrm{MgSO}_{4}$, the solvent was evaporated under reduced pressure. The residue was purified by column chromatography with EtOAc/petroleum ether (1:3, v/v) as an eluent to yield the desired products 4 . For details, see Supporting Information File 1.

\section{Supporting Information}

\section{Supporting Information File 1}

Experimental part.

[http://www.beilstein-journals.org/bjoc/content/

supplementary/1860-5397-9-231-S1.pdf]

\section{Acknowledgements}

Financial supported from the National Natural Science Foundation of China (21002042), the Jiangxi Educational Committee (GJJ12169), the Project of Jiangxi Youth Scientist (20122BCB23012), and the Open Project Program of Key Laboratory of Functional Small Organic Molecule, the Ministry of Education, and the Jiangxi Normal University (No. KLFSKF-201204 and KLFS-KF-201217) is gratefully acknowledged.

\section{References}

1. Cane, D. E. Chem. Rev. 1990, 90, 1089-1103. doi:10.1021/cr00105a002

2. Tietze, L. F. Chem. Rev. 1996, 96, 115-136. doi:10.1021/cr950027e

3. Tietze, L. F.; Modi, A. Med. Res. Rev. 2000, 20, 304-322. doi:10.1002/1098-1128(200007)20:4<304::AID-MED3>3.0.CO;2-8

4. Nicolaou, K. C.; Edmonds, D. J.; Bulger, P. G. Angew. Chem., Int. Ed. 2006, 45, 7134-7186. doi:10.1002/anie.200601872

5. Enders, D.; Grondal, C.; Hüttl, M. R. M. Angew. Chem., Int. Ed. 2007, 46, 1570-1581. doi:10.1002/anie.200603129

6. D'Souza, D. M.; Mueller, T. J. J. Chem. Soc. Rev. 2007, 36, 1095-1108. doi:10.1039/b608235c

7. Phillipson, J. D.; Roberts, M. F.; Zenk, M. H., Eds. The Chemistry and Biology of Isoquinoline Alkaloids; Springer Verlag: Berlin, Germany, 1985. doi:10.1007/978-3-642-70128-3

8. Kartsev, V. G. Med. Chem. Res. 2004, 13, 325-336. doi:10.1007/s00044-004-0038-2

9. Menachery, M. D.; Lavanier, G. L.; Wetherly, M. L.; Guinaudeau, H.; Shamma, M. J. Nat. Prod. 1986, 49, 745-778. doi:10.1021/np50047a001

10. Baker, B. J. Alkaloids: Chem. Biol. Perspect. 1996, 10, 357-407. doi:10.1016/S0735-8210(96)80028-8

11. Lundstroem, J. Alkaloids 1983, 21, 255-327.

12. Croisy-Delcey, M.; Croisy, A.; Carrez, D.; Huel, C.; Chiaroni, A.; Ducrot, P.; Bisagni, E.; Jin, L.; Leclercq, G. Bioorg. Med. Chem. 2000, 8, 2629-2641. doi:10.1016/S0968-0896(00)00194-2

13. Parenty, A. D. C.; Song, Y.-F.; Richmond, C. J.; Cronin, L. Org. Lett. 2007, 9, 2253-2256. doi:10.1021/ol070263z

14. Abet, V.; Nuñez, A.; Mendicuti, F.; Burgos, C.; Alvarez-Builla, J. J. Org. Chem. 2008, 73, 8800-8807. doi:10.1021/jo801549u

15. Ahmed, E.; Briseno, A. L.; Xia, Y.; Jenekhe, S. A. J. Am. Chem. Soc. 2008, 130, 1118-1119. doi:10.1021/ja077444g

16. Fischer, D.; Tomeba, H.; Pahadi, N. K.; Patil, N. T.; Huo, Z.; Yamamoto, Y. J. Am. Chem. Soc. 2008, 130, 15720-15725. doi:10.1021/ja805326f

17. Asao, N.; Yudha, S.; Nogami, S. T.; Yamamoto, Y. Angew. Chem., Int. Ed. 2005, 44, 5526-5528. doi:10.1002/anie.200500795 
18. Asao, N.; Chan, C. S.; Takahashi, K.; Yamamoto, Y. Tetrahedron 2005, 61, 11322-11326. doi:10.1016/j.tet.2005.09.012

19. Ohtaka, M.; Nakamura, H.; Yamamoto, Y. Tetrahedron Lett. 2004, 45, 7339-7341. doi:10.1016/j.tetlet.2004.08.008

20. Huang, Q.; Larock, R. C. J. Org. Chem. 2003, 68, 980-988. doi:10.1021/jo0261303

21. Dai, G.; Larock, R. C. J. Org. Chem. 2003, 68, 920-928. doi:10.1021/jo026294j

22. Dai, G.; Larock, R. C. J. Org. Chem. 2002, 67, 7042-7047. doi:10.1021/jo026016k

23. Huang, Q.; Hunter, J. A.; Larock, R. C. J. Org. Chem. 2002, 67, 3437-3444. doi:10.1021/jo020020e

24. Roesch, K. R.; Larock, R. C. J. Org. Chem. 2002, 67, 86-94. doi:10.1021/j0010579z

25. Roesch, K. R.; Zhang, H.; Larock, R. C. J. Org. Chem. 2001, 66, 8042-8051. doi:10.1021/jo0105540

26. Roesch, K. R.; Larock, R. C. Org. Lett. 1999, 1, 553-556. doi:10.1021/ol990067v

27. Dai, G.; Larock, R. C. Org. Lett. 2001, 3, 4035-4038. doi:10.1021/ol0102085

28. Chen, Z.; Ding, Q.; Yu, X.; Wu, J. Adv. Synth. Catal. 2009, 351, 1692-1698. doi:10.1002/adsc.200900131

29. Chen, Z.; Su, M.; Yu, X.; Wu, J. Org. Biomol. Chem. 2009, 7, 4641-4646. doi:10.1039/b914265g

30. Chen, Z.; Yang, X.; Wu, J. Chem. Commun. 2009, 45, 3469-3471. doi:10.1039/b904498a

31. Yu, X.; Chen, Z.; Yang, X.; Wu, J. J. Comb. Chem. 2010, 12, 374-378. doi:10.1021/cc1000314

32. Yu, X.; Wu, J. J. Comb. Chem. 2009, 11, 895-899. doi:10.1021/cc900079s

33. Yu, X.; Yang, X.; Wu, J. Org. Biomol. Chem. 2009, 7, 4526-4530. doi:10.1039/b913409c

34. Yu, X.; Ding, Q.; Chen, Z.; Wu, J. Tetrahedron Lett. 2009, 50, 4279-4282. doi:10.1016/j.tetlet.2009.05.013

35. Ding, Q.; Wang, Z.; Wu, J. J. Org. Chem. 2009, 74, 921-924. doi:10.1021/jo802076k

36. Ye, S.; Gao, K.; Wu, J. Adv. Synth. Catal. 2010, 352, 1746-1751. doi:10.1002/adsc.201000080

37. Zheng, D.; Chen, Z.; Liu, J.; Wu, J. Org. Biomol. Chem. 2011, 9, 4763-4765. doi:10.1039/c1ob05582h

38. Ye, S.; Wang, H.; Wu, J. Eur. J. Org. Chem. 2010, 6436-6439. doi:10.1002/ejoc.201001040

39. Ye, S.; Wang, H.; Wu, J. ACS Comb. Sci. 2011, 13, 120-125. doi:10.1021/co100026y

40. Yao, B.; Song, R.-J.; Liu, Y.; Xie, Y.-X.; Li, J.-H.; Wang, M.-K.; Tang, R.-Y.; Zhang, X.-G.; Deng, C.-L. Adv. Synth. Catal. 2012, 354, 1890-1896. doi:10.1002/adsc.201101009

41. Ding, Q.; Wang, D.; Sang, X.; Lin, Y.; Peng, Y. Tetrahedron 2012, 68, 8869-8874. doi:10.1016/j.tet.2012.08.039

42. Chen, Z.; Yu, X.; Su, M.; Yang, X.; Wu, J. Adv. Synth. Catal. 2009, 351, 2702-2708. doi:10.1002/adsc.200900442

43. Yeom, H.-S.; Kim, S.; Shin, S. Synlett 2008, 924-928. doi:10.1055/s-2008-1042936

44. Gao, Z.-X.; Wang, M.; Wang, S.; Yao, Z.-J. Org. Lett. 2009, 11, 3678-3681. doi:10.1021/ol901511x

45. Huisgen, R.; Seidl, H.; Wulff, J. Chem. Ber. 1969, 102, 915-925. doi:10.1002/cber.19691020325

46. Wu, J.; Cui, X.; Chen, L.; Jiang, G.; Wu, Y. J. Am. Chem. Soc. 2009, 131, 13888-13889. doi:10.1021/ja902762a

\section{License and Terms}

This is an Open Access article under the terms of the Creative Commons Attribution License

(http://creativecommons.org/licenses/by/2.0), which permits unrestricted use, distribution, and reproduction in any medium, provided the original work is properly cited.

The license is subject to the Beilstein Journal of Organic Chemistry terms and conditions:

(http://www.beilstein-journals.org/bjoc)

The definitive version of this article is the electronic one which can be found at:

doi:10.3762/bjoc. 9.231 